\title{
EU-US trade post-trump perspectives: TTIP aspects related to foreign direct investment and innovation
}

\author{
Andre Jungmittag ${ }^{1} \cdot$ Paul J. J. Welfens ${ }^{2,3,4}$
}

Published online: 20 February 2020

(C) The Author(s) 2020

\begin{abstract}
The international economic debate on the Transatlantic Trade and Investment Partnership (TTIP) has focused mainly on trade induced real income gains while the Foreign Direct Investment (FDI)-related and innovation induced benefits have been largely neglected, although the EU and the US are leading FDI host countries and FDI source countries. Moreover, from a theoretical perspective a knowledge production function has to be considered in order to analyze FDI and innovation dynamics - and this can then be linked to output and economic growth, respectively. It is argued that such a Schumpeterian approach for an open economy is needed to understand deep integration dynamics while the standard CGE model used by Francois et al. (2013) leads to an underestimation of deep integration projects such as TTIP. The panel data estimation of knowledge production functions for $20 \mathrm{EU}$ countries between 2002 and 2012 shows clear empirical evidence that a rise of the number of researchers and of the FDI stock-GDP ratio (or related variables) will raise patent applications. Additionally, a higher per capita income - that could reflect trade related real income gains in the context of TTIP - also contributes to new knowledge and a fortiori to higher GDP. Time series data analysis for Germany indicates additionally that FDI induced higher innovation dynamics will raise output - combining trade benefits and FDI/ innovation related real income gains plus transatlantic macroeconomic interdependency effects a real income gain of nearly $2 \%$ should be expected for Germany (and the EU). As the Trump Administration is focusing on bilateralism, the US is essentially renouncing a considerable output increase and opportunities to improve its current account; instead the Trump Administration has adopted a policy of protectionism which is likely to undermine trade dynamics and economic growth. In the long run, transatlantic trade perspectives could improve.
\end{abstract}

Keywords Knowledge production function - Innovation · FDI - TTIP - Empirical analysis · EU

JEL F14 $\cdot \mathrm{F} 43 \cdot \mathrm{O} 30 \cdot \mathrm{O} 47 \cdot \mathrm{O} 52$

Paul J. J. Welfens

welfens@eiiw.uni-wuppertal.de; http://www.eiiw.eu

Extended author information available on the last page of the article 


\section{Introduction}

The negotiations between the European Union and the US on a Transatlantic Trade and Investment Partnership (TTIP) began in 2013 and were expected conclude in 2016/17 after the end of the Obama administration; political resistance had been particularly strong in Germany, often for rather unclear reasons. With President Trump's administration the US has given up on TTIP and also on the Trans-Pacific Partnership Agreement; it seems that the expected US economic benefits are insufficient to justify broad regional integration schemes. However, there still remains the key issue of which theoretical and empirical approach is appropriate to best assess the benefits from a deep integration scheme such as TTIP, i.e. which would not just focus on trade liberalization but on the reduction of FDI barriers as well. Focusing on TTIP, one may raise questions about the rather narrow European Union's (EU) Commission approach and the Francois et al. (2013) paper that looks mainly at trade aspects and only in chapter 6 - based on an FDI gravity modeling - on some selected aspects of transatlantic Foreign Direct Investment (FDI) liberalization. The subsequent analysis looks, in a broader perspective, at the knowledge production function (KPF) as a methodology to simultaneously consider the role of FDI inward stocks, the number of researchers and a proxy for trade intensity. Based on an empirical panel data analysis we can then plug the results under certain assumptions into the macroeconomic production function of the EU's largest economy, namely Germany, in order to get an assessment of how the combined effects of trade, FDI and innovation affect real output; in a nutshell the same key question can be raised in a kind of reverse perspective of Brexit where the UK is expected to leave the EU single market and thus largely give up on the intra-EU dynamics of trade, FDI and innovation involving UK firms with trade, production and knowledge networks in the EU28 (Welfens 2017). If the UK implements Brexit in 2020, one may assume that the UK and the US would embark on a UK-US free trade agreement within a rather short period of time.

As the US has withdrawn from the TTIP negotiations in 2017 and adopted a broadly protectionist policy stance, the Trump Administration has undermined prospects for strong transatlantic and global trade growth. Moreover, the new US focus on bilateralism is undermining multilateralism in a general way and the functioning of the WTO in particular; the lack of qualified expert staff in the Treasury and the Department of Commerce - as Trump could replace only about 3000 of the 4000 or so political appointments made under the Obama Administration - implies considerable US and Western stabilization risk for the case of a major international economic slow-down (Welfens 2019). With global economic growth slowing down in 2019/2020 - following actual statistics for the US and the October 2019 IMF forecast for 2020 (IMF 2019) one may again raise the question of how big the benefits for the EU and the US would be if both sides would consider a transatlantic free trade agreement: if the EU27 and the UK would embark upon a parallel transatlantic free trade agreement, one should consider the key questions of a Transatlantic Trade and Investment Partnership. Even if the Trump Administration has adopted bilateralism as a preferred policy strategy, this does not exclude new EU-US free trade negotiations since this would still be compatible with bilateralism. The more difficult US-Chinese trade negotiations turn out to be, the more the Trump Administration could be interested in considering a broader 
Transatlantic free trade agreement; however, in a period of US-driven weakening of (and thus declining of) multilateralism, it is not very likely that the Trump Administration will very actively seize the opportunity to liberalize US-EU economic relations. The new EU Commission could be interested in minimizing the negative effects of Brexit, namely by embarking upon a new EU-US free trade agreement; possibly without the much debated international investment treaty, but it is quite unclear that the Commission would push for a Transatlantic Agreement rather soon in a Trumpian environment in which political promises from the US have become rather doubtful messages even for Western allies. Felbermayr (2019) has argued that Trump's protectionism has thus far not undermined global trade. The statistics support the Felbermayr argument to some extent, but one should not overlook that in a US-China-EU perspective the strong US protectionism vis-à-vis China has caused considerable Chinese export diversion towards ASEAN and the EU on the one hand, on the other hand the global price level has reduced under the effect of Chinese tradable goods supplies (i.e. the global price level is lower than in the Business-As-Usual Case) so that there is a rather artificial global real income gain which stimulates trade in a particular way. Moreover, the expansion of information and communication technology is also a new driver the creation of geographically more dispersed production networks so that global trade in intermediate products should increase - and one should indeed control for such effects which apparently has not been the case in the Felbermayr analysis.

Even post-Obama, there is a clear analytical transatlantic trade liberalization issue for the US and the EU and it is largely still the TTIP framework which matters; not only with respect to trade perspectives but also with respect to US foreign direct investment in the EU and EU FDI in the US: Looking at the TTIP issues in this twin perspective is quite interesting and the Trump Administration, or any other populist US presidential administration, would have to focus on the option of TTIP (obviously under a new name) or to consider just narrow sectoral liberalization options such as reducing or eliminating tariffs for the automotive sector and some other sectors. A narrow sectoral tariff liberalization focus would, however, be economically and thus politically less attractive for both the US and the EU on the one hand. On the other hand, the US as the world's largest source country of FDI will always have an interest in reducing investment barriers in the EU and here the European Commission indeed has competences for EU investment treaties since the Lisbon Treaty which created this new competence for the EU in a rather haphazard way (Shan and Zhang 2010).

From an economic perspective, a key question has been how big the potential benefits from TTIP could be and here it is remarkable that no joint EU-US analysis was published. Rather, the EU presented its own study - state of the art in terms of trade modeling, but actually missing key points: The analytical issues related to TTIP are still highly relevant and one of the issues to be considered is why the EU itself has not commissioned a broader study on TTIP; instead the CEPR study (Francois et al. 2013) has mainly looked into the trade-related benefits that were estimated to be rather low while foreign direct investment effects were considered only in a limited way. While one may anticipate that the FDI and innovation effects would be core elements of TTIP dynamics, the European Commission focused only on trade and FDI; the small TTIP benefit identified by the Francois et al. study - basically a $0.5 \%$ increase of GDP in the EU (plus a small impact from the liberalization of transatlantic FDI - contributed to many critical questions on TTIP. Given the fact that the US and the EU are the largest 
source countries of FDI and also stand for two of the three leading FDI host countries globally, it is obvious that FDI aspects should be included in a TTIP analysis; and since the US and the EU are the world's two most innovative countries and since FDI and innovations are closely linked, the FDI patent/innovation nexus should be included in a serious TTIP analysis. However, this has not been done in the study of Francois et al. the subsequent contribution undertakes this task and generates new insights, including that the study by Francois et al. results in a stark underestimation of the benefits of TTIP.

In many EU countries there is a broad discussion about the economic benefits of TTIP - particularly in Germany, Austria and Luxembourg where PEW surveys (2015) on TTIP attitudes suggest that a majority of the population in these countries is against TTIP; and in the US the regional trade project on a Trans-Pacific Partnership - TPP has been signed in 2015 - has also encountered massive political resistance. One key issue concerns the economic benefits for the countries involved. It is well known that the official EU study (Francois et al. 2013) on the TTIP-related benefits suggest a fairly low long run economic gain, namely $0.5 \%$ of GDP for the EU and $0.4 \%$ of GDP for the US. While it is true that Chapter 6 of the Francois et al. study is rarely mentioned, one may argue that this analysis indeed looked beyond pure trade creation effects, namely by asking how much transatlantic FDI flows would be raised if the transatlantic barriers to capital flows would fall by a quarter, namely down to the level of intra-EU capital flows; and the result was a rise in employment by US subsidiaries in the EU of about $11 \%$ and for EU subsidiaries in the US of about $10 \%$. Taking additionally into account BEA data, according to which US subsidiaries in the EU have accounted in 2012 for about $3 \%$ of the EU's gross domestic product while that of EU subsidiaries in the US stand for a similar figure, the implication is that there could be another gain of $0.33 \%$ in the EU and of $0.30 \%$ in the US if labor productivity remains constant in these firms - and if there is no offsetting decline of employment in other firms (not standing for transatlantic foreign subsidiaries).

It is, however, clear that TTIP lets one expect a rise of labor productivity so that the implications of the findings of Francois et al. (2013) imply an output increase that should exceed that of employment in the subsidiaries. While the study of Francois et al. covers at least the main trade aspects and basic FDI perspectives, it is obvious that a broader analysis of FDI and innovation dynamics is not included. It is also not fully clear as to what extent reduction of non-tariff barriers brings about direct output gains through cost cutting by firms as a result of new - common transatlantic - norms. Subsequently, we will take a closer look at this issue and consider the empirical findings for Germany to be an important clue for potential effects for the EU as a whole.

It should be emphasized that in a world economy with economic globalization read: where FDI, trade and innovation dynamics are interacting - it will be important to consider broader international Schumpeterian dynamics, including the particular role of FDI on knowledge accumulation.

- The modern knowledge production function is an adequate approach in this context and this holds not only for OECD countries but for China (Cheung and Lin 2003) as well. 
- It is fairly obvious that it is not only an analysis of the TTIP project which requires a careful look at the concept of a knowledge production function and real income gains; the case of the Trans-Pacific Partnership (TPP) is a similar development which suggests not to simply rely only on a standard Computable General Equilibrium model and some basic gravity equation modeling (even if the US pulls out of TPP, the other 11 countries seem to be willing to start the political venture - at first without the US).

The EU and the US are the main source countries of global foreign direct investment and they stand for two of the three main host countries (with the EU considered here as a quasi-country); they also stand for about $30 \%$ of triad patents and it is well known that FDI dynamics and patent applications are often positively linked. In the context of the EU-US Transatlantic Trade and Investment Partnership, one may expect that a rising inward foreign direct investment in EU countries could directly or indirectly affect real income. At first glance the inward FDI dynamics have three basic aspects:

- Inward FDI could be reduced in a transatlantic perspective, namely to the extent that reduced import tariffs in the EU (or the US) will weaken previous tariffjumping motivation. Given the fact that import tariff levels in the US and the EU were about $3 \%$ at the start of the TTIP negotiations on both sides of the Atlantic, one may, however, expect this aspect to be rather weak. With non-tariff barriers estimated to amount to a tariff equivalent of about $17 \%$ in the EU (based on the CEPR report and assuming that industry stands for $60 \%$ and services for $40 \%$ of trade) - and with similar levels in the US - one cannot rule out that NTB reductions could make this aspect somewhat temporarily relevant.

- With transatlantic investment barriers to be reduced additional transatlantic FDI inflows can be expected in EU countries - and higher EU FDI outflows to the US. A rise of transatlantic FDI might not only reflect lower barriers to international investment but could also stand for increasingly complex global value-added chains that are facilitated by modern information and communication technologies (ADB 2015).

- FDI inflows from third countries can be expected in the context of TTIP and this to some extent is indeed the tariff-jumping argument in a modified perspective mentioned in the first aspect. For example, investors from China, ASEAN countries or Latin American countries can be expected to be interested in raising production in the EU (and the US), respectively. In oligopolistic industries one may expect additional inflows in the context of follow-the-leader FDI pattern.

With higher foreign direct investment inflows - and hence a higher role of multinational companies, most of which are technology-intensive -, one can focus on knowledge production functions and the role of (cumulated) FDI inflows on the production of new knowledge. However, in the presence of inward FDI and outward FDI it is necessary to make a distinction between the effects of deep regional integration on gross domestic income (Y) and gross national income $(\mathrm{Z})$ : 
- Real income $\mathrm{Z}$ is obtained as $\mathrm{Y}$ plus net income from abroad so that net dividend payments received are a crucial element to be considered - and here the stock of inward FDI and of outward FDI naturally will play a role.

- Hence of one wants to understand how FDI and innovation dynamics, respectively, affect real national income one will have to look beyond GDP effects - in any case the innovation dynamics and the knowledge production function will be key aspects to be considered.

The analytical concept of a knowledge production function is well established in the literature and indeed has been applied in various ways to industrialized countries (Charlot et al. 2014; Fritsch 2002; Marrocu et al. 2013); this concept assumes that new knowledge, approximated by patent applications for example, is based on a specific macroeconomic knowledge production function including researchers and FDI capital stocks as well as other variables. While looking at patent application is a common way to proxy new knowledge, one may emphasize that not all new knowledge is patented - possibly a declining share of it can be protected by patents in modern services economies. However, in a pragmatic empirical perspective patent applications are still crucial for analyzing knowledge progress in industrialized countries.

The paper is organized as follows. At first we take a brief look at some basic aspects of trade and productivity growth in regional trade liberalization approaches. Key insights from the literature are summarized. Next, a compact knowledge production function is developed in a new approach for an open economy and this represents the basic theoretical basis for the subsequent regression analysis which in turn allows to calculate the overall GDP effects for the EU; this will include trade effects, FDI and innovation effects plus the transatlantic macroeconomic spillover effect from the US GDP to the EU GDP. Finally, selected policy conclusions from the empirical findings are presented with some particular conclusions for the case of Germany. The order of magnitude that comes out as the grand total for the EU is about $2 \%$. In principle, the methodology developed here could also be applied to the US on the basis of a Schumpeterian regional US model (with states instead of EU countries considered here). The policy conclusions stated in the end are not only picking up the key insights from the panel data estimation of the knowledge production function for $20 \mathrm{EU}$ countries in the period 2002-2012. Rather there is also a need to consider not only the implications for the EU policy layer but for the national policy layer as well and to take into account that differences in intra-EU FDI and innovation dynamics could considerably reinforce economic divergence within the European Union. One may also emphasize that policy reforms that enhance the respective national innovation system.

The analytical approach used in the context of the knowledge production function is to understand deep integration projects such as the EU-US project of a Transatlantic Trade and Investment Partnership - potentially also the TPP project of the US with eleven partner countries from the Pacific Basin including Australia and Japan - indeed should go beyond the analysis of trade creation and trade diversion. While President Obama had signed the TPP project, his successor Donald Trump has decided to stop TPP and indeed the US effectively had soon withdrawn from three treaties and international institutions, respectively: 
- The US turned its back on TPP which began under a different name by the eleven partner countries. Japan, which had joined the negotiation process rather late, became the new de facto leader of this trans-Pacific integration scheme once the US dropped out.

- The Trump Administration withdrew from the UN's Paris Climate Agreement of 2015 in a move which would take effect in late 2020.

- In December 2019, the dispute resolution mechanism of the WTO became dysfunctional since the Trump Administration did not want to contribute to the process of the election of new judges to the WTO's appellate body.

Since patents and innovation, respectively, play a very strong role in the EU and the US, it is clear that TTIP should have a complementary Schumpeterian dimension and this is what we present here with respect to EU countries. The FDI dynamics, the associated Schumpeterian innovation effects and the associated output effects should be studied - a priori it is not clear whether or not there are direct effects of cumulated FDI capital on output or whether only indirect effects are relevant. As will be shown for the case of Germany, which represents about one quarter of the EU's GDP, it is indeed not FDI that has a direct impact on output; the relevant channel is clearly from (cumulated) FDI to knowledge and from knowledge to the macroeconomic production function and output, respectively. From this perspective, chapter 6 of the Francois et al. study should be interpreted with care since employment in US subsidiaries in the US might increase at the expense of the domestic competitors in the EU host countries.

The analysis is organized as follows: Section 2 takes a look at the theoretical background of the knowledge production function and section 3 gives the empirical results of the panel data analysis for 20 EU countries. Section 4 considers the results of plugging the knowledge production function findings into a well-known macro production function for Germany that was originally calculated for the German Institute for Standardization/DIN (an approach that has also been applied to some other countries). Section 5 looks at the implications of FDI inflows for Germany's output so that one major EU country is considered - as an example for the whole EU: We provide empirical evidence on the issue of whether or not FDI has a direct effect on output. Section 6 gives some policy conclusions and the appendix points out the relevance of the distinction between GDP and gross national income in a setting with FDI. The fact that the figures for Germany, Spain, the UK, the US and other OECD countries show no significant difference between GDP and GNP figures could have various explanations; partly it seems to be an artefact in the context of the tax evasion of firms as can be shown, for example, in the case of Spain where hidden Spanish investment in Switzerland is partly hiding considerable extra foreign dividend income accruing to Spanish investors (Welfens 2019).

\section{Trade, FDI and Schumpeterian dynamics: Framework for innovation dynamics and an open economy knowledge production function}

As regards the link between trade expansion and competition and real income, respectively, a brief look at the traditional literature is useful. There is a rather direct trade expansion-competition dynamics-real income effect that is related to modern trade 
theory in an oligopolistic setting - a case that is likely to be highly relevant in several sectors in an EU + US market perspective. The theoretical approach relevant here is Atkeson and Burstein (2008), namely a model with an oligopolistic market setting and pro-competitive effect from trade. For any given producer the demand elasticity is declining in its market share and therefore its markup is increasing in its market share. The pro-competitive effect of trade means that the initial high markup dispersion implying misallocation of resources - and the market power of hitherto dominant producers will be reduced and this implies a real income and a welfare gain, respectively; for this there is rich empirical evidence, e.g. for the case of Taiwan (Edmond et al. 2015). As the authors rightly emphasize: As the market shares of the dominant producers are reduced, international trade will both reduce markups and also markup dispersion so that allocation efficiency is improved. In a transatlantic TTIP perspective, the implication is that the market entry of new firms from EU countries and third countries in the US and of new firms from the US and third countries in the European Union single market could bring about directly trade-related efficiency gains, higher Schumpeterian dynamics and real income gains, respectively. A key issue in open economies is how factor inputs are related to the innovation process and here the analytical focus has indeed to consider the knowledge production function.

\subsection{Knowledge production function}

The knowledge production function is a workhorse of modern innovation analysis and has been pushed by several innovative economists, including Machlup (1979), Griliches (1979) and - in a recent perspective - new research with a focus on Russia (Perret 2014) and US-focused research from the IMF (Abdih and Joutz 2005). The knowledge production function explains knowledge, often proxied by the stock of patents, by specific inputs such as researchers, foreign direct investment (Antonietti et al. 2015 on Italy; Bottazzi and Peri 2003 on EU countries; Cheung and Lin 2004 in a regional perspective on China) and other inputs. The subsequent knowledge function builds on Welfens (2016) who has suggested that one should consider trade input effects, researchers' input and FDI inward stock effects as well as FDI outward effects:

- As regards the volume of exports $\mathrm{X}$, there is a traditional argument about efficiency gains so that $\mathrm{X} / \mathrm{L}$ (here $\mathrm{L}$ denotes population and labor, respectively) is considered to a natural element of the knowledge production function: A modern approach for an economy with heterogeneous firms is the model of Melitz (2003) where the mechanism for export-related productivity gains stems from the fact that opening up the economy lets the most productive firm(s) expand while the least productive firms in the export sector will close down. This implies that exports should stimulate the aggregate new knowledge (A') and thus the stock of knowledge (A) as, say, approximated by patent applications and the stock of patents, respectively. It will be assumed that the familiar eq. $\mathrm{X}=\mathrm{xY} \mathrm{Y}^{*}(*$ for foreign variables, $0<\mathrm{x}<1)$ is holding.

- As regards the volume of imports J, one may argue that particularly technologyintensive intermediate inputs contribute to output gains as the empirical evidence of Coe and Helpman (1995) suggests. It is, however, true that Keller (2000) has raised some doubts about the Coe-Helpman approach which basically implied that a 
country that relies on strong intermediate import links with countries with relatively high increases in total factor productivity growth would obtain high output gains from higher imports in intermediate products. Here it will be assumed that imports per capital $\mathrm{J} / \mathrm{L}$ are conducive to knowledge. It will, of course, have to be taken into account that $\mathrm{J}=\mathrm{jY}$ - in line with standard import function $(0<\mathrm{j}<1)$.

- It will be assumed that the size of the research sector - reflecting direct research input - contributes to new knowledge.

- Moreover, one may assume that FDI stocks relative to output contributes to patents and knowledge, respectively; namely, since multinational companies in a world of economic globalization typically stand for technology-intensive production and considerable product innovation and process innovation dynamics organized through international production networks (Dunning 1977). The share of foreign ownership in country 1's capital stock will be denoted by $\alpha^{*}$ so that $\alpha^{*} \mathrm{~K}$ is equivalent to the inward FDI capital stock $\mathrm{K}^{* *}$ (finally, in the context of assetseeking FDI outflows - with firms interested in acquiring new knowledge abroad and later transferring part of it back to the parent company - one may assume that the outward FDI stock variable also could play a role for international knowledge transfer).

If one considers a simple knowledge production function, one will have to consider (with L' denoting researchers): $\mathrm{A}^{\prime}(\mathrm{X} / \mathrm{L}, \mathrm{J} / \mathrm{L}, \mathrm{L}$, FDI inward stock/Y) where it is specified (with $\mathrm{K}$ denoting the capital stock; parameters $\mathrm{H}>0, \mathrm{~V}^{\prime}>0, \mathrm{~V}^{\prime \prime}>0, \mathrm{~V}>0$ ):

$$
\mathrm{A}^{\prime}=(\mathrm{X} / \mathrm{L})^{\mathrm{H}}(\mathrm{J} / \mathrm{L})^{\mathrm{V}^{\prime}}\left(\mathrm{L}^{\prime}\right)^{\mathrm{V}^{\prime \prime}}(\alpha * \mathrm{~K} / \mathrm{Y})^{\mathrm{V}}
$$

Taking into account that $\mathrm{X}=\mathrm{xY} \mathrm{Y}^{*}$ and $\mathrm{J}=\mathrm{jL}$ we can write (with $\mathrm{K}$ for the capital stock in the economy, per capita income $y:=Y / L)$ :

$$
\begin{aligned}
& \mathrm{A}^{\prime}=(\mathrm{x}(\mathrm{Y} * / \mathrm{Y}) \mathrm{y})^{\mathrm{H}}(\mathrm{jy})^{\mathrm{V}^{\prime}}\left(\mathrm{L}^{\prime}\right)^{\mathrm{V}^{\prime \prime}}\left(\alpha^{*} \mathrm{~K} / \mathrm{Y}\right)^{\mathrm{V}} .
\end{aligned}
$$

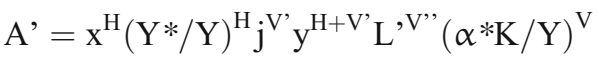

Hence knowledge is a positive function of $x$ (export-GDP ratio), $\mathrm{j}$ (import-GDP ratio), $\mathrm{Y}^{*} / \mathrm{Y}, \mathrm{y}, \mathrm{L}$ ' and the inward FDI stock-GDP ratio. A more compact function - as is used subsequently - will look at $\mathrm{A}^{\prime}\left(\mathrm{L}^{\prime}, \mathrm{y}, \alpha^{*} \mathrm{~K} / \mathrm{Y}\right)$, which may be interpreted as a setup in which the number of researchers, trade intensity as proxied by per capita income, and the inward FDI globalization intensity (parameter $\alpha^{*}$ ) play a critical role for knowledge and patent applications, respectively. From this perspective, the relative FDI inward stock which represents part of economic globalization intensity should indeed play a major role for creation of new knowledge. This type of knowledge production function has been developed in Welfens (2016) and to the extent that the knowledge stock function is empirically analyzed it can easily be plugged into a macroeconomic production function; say (with $\mathrm{Y}$ denoting real output; $0<\beta<1$; A is the stock of 
knowledge), a Cobb-Douglas function $\mathrm{Y}=\mathrm{K}^{\beta}(\mathrm{AL})^{1-\beta}$ or a CES function which is better suited for analyzing income distribution issues.

The approach considered here for a knowledge-output interrelationship in the context of our subsequent panel-data results for patent applications (new knowledge $\mathrm{A}^{\prime}$ ) is to basically link the knowledge production function with the macroeconomic production function; a simplified way is to assume that the elasticity of new knowledge with respect to output is the same as the elasticity of the stock of knowledge with respect to output which is valid only in the steady state with a constant ratio of $\mathrm{A}^{\prime} / \mathrm{A}$ (if $\mathrm{a}:=\mathrm{A}^{\prime} / \mathrm{A}$ is constant, then the growth rate of $\mathrm{A}^{\prime}$ is the same as that of $\mathrm{A}$. It is also clear that $A(t)=A_{t-1}+A^{\prime}$, however for an empirical implementation in the context of a CobbDouglas production function the subsequent implications of the empirical finding for $A^{\text {' }}$ is not easily implemented into this macro production function or a CES function. To what extent FDI directly or indirectly affects output will also have to be considered the indirect effect coming from the fact that cumulated FDI indeed plays a role in the knowledge production function and knowledge, in turn, is an input in the macro production function.

\section{Regression analysis: Panel data estimation for knowledge production functions of $20 \mathrm{EU}$ countries in 2002-2012}

Taking a look at 20 EU countries for the period 2002-2012 one can focus in an empirical analysis on the knowledge productions in the most important EU countries with relevant data available. As regards the subsequent panel data analysis, one cannot rule out cross-country innovation spillover/knowledge generation effects. However, a different approach would be needed to study such effects. To the extent that such spillovers are linked to FDI, the FDI stock variable to be considered should cover part of this aspect; and the fixed effect might also reflect to some extent relatively large or relatively weak international spillover effects.

The subsequent panel data analysis includes time effects and fixed country effects where significant and allows identifying a significant impact of cumulated inward FDI on knowledge production where the countries' respective patent applications (proxy for new knowledge) at the European Patent Office are considered. All variables used are in logs.

The explanatory variables are:

- RDPERS: personnel in research and development in the countries considered (source: OECD)

- RDEXPDOLLAR: R\&D expenditures in constant prices and purchasing power parity, in US\$ source: OECD).

- RDEXPEURO: R\&D expenditures in constant prices and purchasing power parity, in euro (source: EUROSTAT).

- PGDPDOLLAR: GDP per capita in constant prices and purchasing power parity, USD (source: OECD).

- PGDPEURO: Real GDP per capita in euro (chained volume indices; source: EUROSTAT). 
- FDISTOCK: Stock of inward foreign direct investment in the countries considered in euro (source: EUROSTAT).

- FDISTOCKQ: stock of FDI in the countries considered, expressed as share of GDP (source: EUROSTAT).

The GDP per capita variables are included in the estimations to reflect the import variable indirectly and also to account for the fact that the countries in the EU are at different stages of economic development so that their innovation capabilities will also differ. A positive impact of this variable would indicate that economically higher developed EU countries tend to be more productive in their R\&D activities. This result would not be surprising because the level of human capital, infrastructure, and so on are in general positively correlated to the level of economic development. This would support other theoretical and empirical findings that the level of economic development is a major determinant of innovation activities across countries.

In the first regression analysis, which includes as explanatory variables the number of researchers ( $R \& D$ personnel at full time equivalent), the per capita GDP in \$ (in constant prices and at purchasing power parity) and the inward FDI stock relative to GDP, all exogenous variables are significant and with a positive sign (see the subsequent tables). The elasticity of patent applications with respect to researchers is 0.35 while that of the cumulated inward FDI-GDP ratio is 0.16 . The elasticity of new knowledge with respect to per capita income is 1.82 and is fairly high. The test statistics shows that coefficients presented are highly significant.

The fixed country effect is significantly positive for several countries: Austria, Belgium, Denmark, Finland, France, Germany, Italy, the Netherlands, Spain, Sweden and the UK. The negative signs for the Czech Republic, Greece, Ireland, Luxembourg, Poland, Portugal, Slovakia and Slovenia indicate that some EU cohesion countries and some Eastern European EU countries will have lower benefits than average (and Luxembourg, with its high share of banking and other services, as well; for those countries with a rather low per capita income, a sustained long-term convergence process could still bring similar benefits to those for most EU15 countries in the long run; adequate policy reforms in the innovation systems could be crucial here as could the optimization of government R\&D promotion).

As regards the largely satisfactory test statistics, it should be noted that the adjusted R2 falls from 0.99 to 0.9 if the country fixed effects are dropped. Thus the model seems to be fairly robust. Similar findings hold for modified models considered subsequently. In the context of other integration groups (e.g. TPP), it might be adequate to consider a broader range of variables as suggested in the theoretical section. It should be noted at this stage that the results from our preferred model 1 will be used later to be plugged into the macroeconomic production function. In the modified knowledge production function in Table 2, the number of researchers has been replaced by the real R\&D expenditures of the respective country. The elasticity for the research variable is now somewhat higher, the coefficient for the per capita GDP variable is smaller and the coefficient for the FDI inward stock-GDP ratio is smaller than in model 1. 
Model 2 in Table 2 considers as an alternative to researchers the real R\&D expenditures in \$USD as an explanatory variable. There is still a positive significant impact - with significance levels falling slightly (one-sided at the 5\% level, two-sided at the $10 \%$ level). Model 3 has replaced the per capita real \$USD GDP in PPP figures by the corresponding figures in €EURO - the impact of the FDI inward stock relative to GDP is unchanged when compared to Table 1; this also holds for the other coefficients of the variables considered. Model 4 replaces the real R\&D expenditures in USD by the real expenditures in EURO: with roughly the same results as in Model 2 (Tables 3, 4, 5 and 6).

Model 5 (with R\&D personnel) and Model 6 (with R\&D personnel substituted by real R\&D expenditures in $€ E U R O /$ at PPP) replace the inward FDI stock-GDP ratio by the nominal FDI stock figures; this operation has the natural caveat that nominal FDI stock figures could not be deflated by an adequate price level, but the coefficients are highly significant. In Model 6 the time fixed effects that affect all countries over time in a parallel fashion are also significant. In the period between 2002 and 2006 the time dummy (model 6) was positive, while in the period 2007-2012 there is a negative impact whose underlying source is unclear; one might presume that the Transatlantic Banking Crisis had a joint impact on the countries considered.

At the bottom line, the knowledge production function for EU20 countries considered here works well and clearly indicates both a positive impact of real per capita GDP and of FDI inward stocks. Thus we have quite interesting complementary findings to the study of Francois et al. (2013) that had already indicated benefits of $0.5 \%$ of GDP from trade and additional employment benefits - and thus an implicit GDP increase of $0.33 \%$ - from higher FDI inflows due to reducing transatlantic FDI barriers. One may add to this the induced innovation dynamics in the context of TTIP, namely based on the findings for the knowledge production function for 20 EU countries in 2002-2012. The panel regression analysis is robust with various specifications and clearly indicates that a higher per capita income and a rise of inward FDI figures will translate into more patent applications.

\section{The knowledge production function results and the macro production function}

If one wants to consider the impact of new knowledge and knowledge, respectively, on GDP, some specific reflections are adequate. If one considers a situation with a long run equilibrium in which the growth rate of knowledge $\left(a:=A^{\prime} / A\right)$ is constant, the elasticity of $Y$ with respect to new knowledge $A^{\prime}$ is the same as the elasticity of $\mathrm{Y}$ with respect to the stock of knowledge A. This follows from the fact that a constant growth rate of knowledge a implies that the growth rate of $\mathrm{A}^{\text {' }}$ will be equal to that of $\mathrm{A}$. There are some natural caveats regarding whether or not this is an adequate approach for looking at the link between the knowledge production function and the macro production function. Ideally, we would have a knowledge production function that looks at changes in stocks and that can be integrated, e.g.: $A^{\prime}=b d K / d t+b^{\prime} d^{* *} / d t+d R^{\prime} / d t\left(b, b^{\prime}\right.$ and $b^{\prime \prime}$ are positive parameters) where $\mathrm{K}^{* *}$ is the inward capital stock of foreign investors and $\mathrm{R}^{\prime}$ the change in the $R \& D$ capital stock (this in turn could be calculated on the basis of a 
Table 1 Basic Knowledge Production Function for EU20 Countries.

Dependent Variable: LOG(PAT?)

Method: Pooled Least Squares.

Date: 01/14/16 Time: 17:10.

Sample: 20022012.

Included observations: 11.

Cross-sections included: 20.

Total pool (unbalanced) observations: 205.

Variable

C

LOG(RDPERS?)

LOG(PGDPDOLLAR?)

LOG(FDISTOCKQ?)

Fixed Effects (Cross)

\begin{tabular}{|c|c|}
\hline $\mathrm{AT}-\mathrm{C}$ & 0.522542 \\
\hline $\mathrm{BE}-\mathrm{C}$ & 0.384865 \\
\hline $\mathrm{CZ}-\mathrm{C}$ & -0.911734 \\
\hline $\mathrm{DK}-\mathrm{C}$ & 0.118808 \\
\hline $\mathrm{FI}-\mathrm{C}$ & 0.432950 \\
\hline $\mathrm{FR}-\mathrm{C}$ & 1.701492 \\
\hline $\mathrm{DE}-\mathrm{C}$ & 2.471143 \\
\hline $\mathrm{GR}-\mathrm{C}$ & -1.365439 \\
\hline $\mathrm{HU}-\mathrm{C}$ & -0.343212 \\
\hline $\mathrm{IE}-\mathrm{C}$ & -1.054935 \\
\hline $\mathrm{IT}-\mathrm{C}$ & 1.424113 \\
\hline $\mathrm{LU}-\mathrm{C}$ & -2.833316 \\
\hline $\mathrm{NL}-\mathrm{C}$ & 0.804435 \\
\hline $\mathrm{PL}-\mathrm{C}$ & -0.270742 \\
\hline $\mathrm{PT}-\mathrm{C}$ & -1.450550 \\
\hline $\mathrm{SK}-\mathrm{C}$ & -1.585013 \\
\hline $\mathrm{SI}-\mathrm{C}$ & -0.856756 \\
\hline $\mathrm{ES}-\mathrm{C}$ & 0.238784 \\
\hline $\mathrm{SE}-\mathrm{C}$ & 0.739902 \\
\hline $\mathrm{UK}-\mathrm{C}$ & 1.326632 \\
\hline
\end{tabular}

Effects Specification

Cross-section fixed (dummy variables)

R-squared

0.993230

Adjusted R-squared

0.992411

S.E. of regression

0.156371

Sum squared resid

4.450218

Log likelihood

101.6984

F-statistic

1213.621

Prob(F-statistic)

$\begin{array}{lll}\text { Std. Error } & \text { t-Statistic } & \text { Prob. } \\ 1.936751 & -8.649851 & 0.0000 \\ 0.091091 & 3.895492 & 0.0001 \\ 0.194151 & 9.369062 & 0.0000 \\ 0.074407 & 2.209453 & 0.0284\end{array}$

0.0000

0.0001

0.0284 
Table 2 Modified Knowledge Production Function (with real R\&D expenditures) for EU20.

Dependent Variable: LOG(PAT?)

Method: Pooled Least Squares.

Date: 01/14/16 Time: 17:12.

Sample: 20022012.

Included observations: 11.

Cross-sections included: 20.

Total pool (unbalanced) observations: 210.

$\begin{array}{lllll}\text { Variable } & \text { Coefficient } & \text { Std. Error } & \text { t-Statistic } & \text { Prob. } \\ \text { C } & -12.44756 & 1.762885 & -7.060905 & 0.0000 \\ \text { LOG(RDEXPDOLLAR?) } & 0.537839 & 0.081565 & 6.593998 & 0.0000 \\ \text { LOG(PGDPDOLLAR?) } & 1.345979 & 0.198476 & 6.781574 & 0.0000 \\ \text { LOG(FDISTOCKQ?) } & 0.114961 & 0.065142 & 1.764770 & 0.0792\end{array}$

Fixed Effects (Cross)

$\begin{array}{cl}\text {-AT-C } & 0.419395 \\ \text {-BE-C } & 0.338724 \\ \text {-CZ-C } & -0.807431 \\ \text { _DK-C } & 0.182815 \\ \text { _FI-C } & 0.411436 \\ \text {-FR-C } & 1.276797 \\ \text {-DE-C } & 1.907172 \\ \text { _GR-C } & -1.058098 \\ \text {-HU-C } & -0.244065 \\ \text {-IE-C } & -0.817255 \\ \text { _IT-C } & 1.116557 \\ \text { _LU-C } & -2.001544 \\ \text {-NL-C } & 0.764270 \\ \text {-PL-C } & -0.265500 \\ \text {-PT-C } & -1.338985 \\ \text {-SK-C } & -1.018895 \\ \text {-SI-C } & -0.557203 \\ \text { ES-C } & 0.091877 \\ \text { _SE-C } & 0.569745 \\ \text { _UK-C } & 1.026721\end{array}$

Effects Specification

Cross-section fixed (dummy variables)

R-squared

0.994162

Mean dependent var

6.705092

Adjusted R-squared

0.993475

S.E. of regression

0.145005

S.D. dependent var

1.795074

Akaike info criterion

$-0.921050$

Sum squared resid

3.931939

Schwarz criterion

$-0.554462$

Log likelihood

119.7103

Hannan-Quinn criter.

$-0.772852$

F-statistic

1447.371

Durbin-Watson stat

1.213643

Prob(F-statistic)

0.000000 
Table 3 Modified Knowledge Production Function (per capita GDP in \$, purchasing power parity) for EU20.

Dependent Variable: LOG(PAT?)

Method: Pooled Least Squares.

Date: 01/14/16 Time: 17:18.

Sample: 20022012.

Included observations: 11.

Cross-sections included: 20.

Total pool (unbalanced) observations: 205.

Variable

C

LOG(RDPERS?)

LOG(PGDPEURO?)

LOG(FDISTOCKQ?)

Fixed Effects (Cross)

$\begin{array}{cl}\text {-AT--C } & 0.268028 \\ \text {-BE--C } & 0.101278 \\ \text {-CZ--C } & -0.401791 \\ \text { _DK--C } & -0.523151 \\ \text {-FI--C } & 0.032875 \\ \text { _FR--C } & 1.410926 \\ \text { _DE--C } & 2.313064 \\ \text { _GR--C } & -1.291378 \\ \text {-HU--C } & 0.518174 \\ \text {-IE--C } & -1.313453 \\ \text { _IT--C } & 1.306225 \\ \text { _LU--C } & -3.253928 \\ \text {-NL--C } & 0.531379 \\ \text {-PL--C } & 0.585815 \\ \text {-PT--C } & -1.186308 \\ \text {-SK--C } & -0.930569 \\ \text {-SI--C } & -0.619820 \\ \text {-ES--C } & 0.272321 \\ \text {-SE--C } & 0.276426 \\ \text { _UK--C } & 1.150189\end{array}$

Effects Specification

Cross-section fixed (dummy variables)

R-squared

0.993219

Adjusted R-squared

0.992400

S.E. of regression

0.156487

Sum squared resid

4.456873

Log likelihood

101.5453

F-statistic

1211.797

Prob(F-statistic)

Std. Error
1.883948
0.091158
0.194324
0.074469

t-Statistic

Prob.

$-8.577550$

0.0000

3.895906

0.0001

9.347541

0.0000

2.210130

0.0283 
Table 4 Modified Knowledge Production Function (including real R\&D expenditures in euro) for EU20.

Dependent Variable: LOG(PAT?)

Method: Pooled Least Squares.

Date: 01/14/16 Time: 17:19.

Sample: 20022012.

Included observations: 11.

Cross-sections included: 20.

Total pool (unbalanced) observations: 210.

Variable

C

LOG(RDEXPEURO?)

LOG(PGDPEURO?)

LOG(FDISTOCKQ?)

Fixed Effects (Cross)

\begin{tabular}{|c|c|}
\hline $\mathrm{AT}-\mathrm{C}$ & 0.219228 \\
\hline $\mathrm{BE}-\mathrm{C}$ & 0.125677 \\
\hline $\mathrm{CZ}-\mathrm{C}$ & -0.453155 \\
\hline $\mathrm{DK}-\mathrm{C}$ & -0.253303 \\
\hline $\mathrm{FI}-\mathrm{C}$ & 0.115256 \\
\hline $\mathrm{FR}-\mathrm{C}$ & 1.047851 \\
\hline $\mathrm{DE}-\mathrm{C}$ & 1.761356 \\
\hline GR $-\mathrm{C}$ & -1.001768 \\
\hline $\mathrm{HU}-\mathrm{C}$ & 0.440353 \\
\hline $\mathrm{IE}-\mathrm{C}$ & -1.000190 \\
\hline IT $-\mathrm{C}$ & 1.035358 \\
\hline LU $-\mathrm{C}$ & -2.275746 \\
\hline $\mathrm{NL}-\mathrm{C}$ & 0.550888 \\
\hline $\mathrm{PL}-\mathrm{C}$ & 0.382176 \\
\hline PT $-C$ & -1.126522 \\
\hline _SK-C & -0.510722 \\
\hline SII-C & -0.411760 \\
\hline ES - C & 0.113849 \\
\hline SE-C & 0.223491 \\
\hline UK-C & 0.828525 \\
\hline
\end{tabular}

Effects Specification

Cross-section fixed (dummy variables)

R-squared

0.994163

Adjusted R-squared

0.993476

S.E. of regression

0.144986

Sum squared resid

3.930892

Log likelihood

119.7382

F-statistic

1447.759

Prob(F-statistic)

0.000000
Std. Error

1.706338

t-Statistic

Prob.

0.082207

$-6.957536$

0.0000

0.198022

6.623847

0.0000

6.794765

0.0000

0.065551

1.646522

0.1013
Mean dependent var

6.705092

S.D. dependent var

1.795074

Akaike info criterion

$-0.921316$

Schwarz criterion

$-0.554728$

Hannan-Quinn criter.

$-0.773119$

Durbin-Watson stat

1.208654 
Table 5. Modified Knowledge Production Function (including FDI stocks, real GDP per capita in Euro; fixed time effects significant).

Dependent Variable: LOG(PAT?)

Method: Pooled Least Squares.

Date: 01/14/16 Time: 17:23.

Sample: 20022012.

Included observations: 11.

Cross-sections included: 20.

Total pool (unbalanced) observations: 205.

\begin{tabular}{|c|c|c|c|c|}
\hline Variable & Coefficient & Std. Error & $\mathrm{t}$-Statistic & Prob. \\
\hline $\mathrm{C}$ & -10.17503 & 2.660382 & -3.824650 & 0.0002 \\
\hline LOG(RDPERS?) & 0.321715 & 0.106919 & 3.008950 & 0.0030 \\
\hline LOG(PGDPEURO?) & 1.029031 & 0.253933 & 4.052366 & 0.0001 \\
\hline LOG(FDISTOCK?) & 0.264791 & 0.041364 & 6.401404 & 0.0000 \\
\hline
\end{tabular}

Fixed Effects (Cross)

\begin{tabular}{|c|c|}
\hline AT--C & 0.451870 \\
\hline BE--C & 0.150762 \\
\hline CZ--C & -0.117752 \\
\hline DK--C & -0.198310 \\
\hline FI--C & 0.223155 \\
\hline FR--C & 0.942703 \\
\hline DE--C & 1.857010 \\
\hline GR--C & -1.336617 \\
\hline HU--C & 0.378829 \\
\hline _IE--C & -1.015568 \\
\hline IT--C & 0.891952 \\
\hline LUU--C & -2.119431 \\
\hline NL--C & 0.420483 \\
\hline _PL--C & 0.229157 \\
\hline -PT--C & -1.358396 \\
\hline SK--C & -0.520682 \\
\hline _SI--C & -0.275323 \\
\hline ES--C & -0.168292 \\
\hline SE--C & 0.401912 \\
\hline _UK--C & 0.609319 \\
\hline \multicolumn{2}{|c|}{ Fixed Effects (Period) } \\
\hline 2002--C & 0.007630 \\
\hline 2003--C & 0.099136 \\
\hline 2004--C & 0.109009 \\
\hline 2005--C & 0.064083 \\
\hline 2006--C & 0.058532 \\
\hline 2007--C & -0.005833 \\
\hline 2008--C & -0.040857 \\
\hline 2009--C & -0.031994 \\
\hline
\end{tabular}


Table 5. (continued)

\begin{tabular}{llll}
\hline \hline $2010-\mathrm{C}$ & -0.092863 & \\
$2011-\mathrm{C}$ & -0.089422 & & \\
$2012-\mathrm{C}$ & -0.077421 & & \\
\multicolumn{4}{c}{ Effects Specification } \\
Cross-section fixed (dummy variables) & \\
Period fixed (dummy variables) & & \\
R-squared & 0.994674 & Mean dependent var & 6.740298 \\
Adjusted R-squared & 0.993683 & S.D. dependent var & 1.795015 \\
S.E. of regression & 0.142672 & Akaike info criterion & -0.910104 \\
Sum squared resid & 3.501103 & Schwarz criterion & -0.375180 \\
Log likelihood & 126.2856 & Hannan-Quinn criter. & -0.693740 \\
F-statistic & 1003.738 & Durbin-Watson stat & 1.163770 \\
Prob(F-statistic) & 0.000000 & & \\
\hline
\end{tabular}

perpetual inventory method as has been done in, for example, Welfens et al. (2008). We can then write $A=b K+b^{\prime} K^{* *}+b$ " $R$ where $R$ is the stock of $R \& D$ capital. Whether there is a clear theoretical basis for the above knowledge function is an open question and will not be discussed here. An alternative that can also be analyzed is to focus on a knowledge production function for the stock of knowledge, say $A=(R / L)^{\mathrm{h}}(y)^{\mathrm{h}^{\prime}}\left(\mathrm{K}^{* *} / \mathrm{Y}\right)^{\mathrm{h}}$ " where $\mathrm{R} / \mathrm{L}$ is the share of researchers in the total labor force. This function can directly be plugged into the macroeconomic production function and results thus in a "Schumpeterian production function" that stands for an integrated endogenous knowledge approach (Welfens 2016).

In this contribution, results from the knowledge production function referring to patent applications will be used and the rather pragmatic assumption that the elasticity of output with respect to new knowledge is the same as the elasticity of output with respect to the stock of knowledge is made. The elasticities of the macro production function of Germany used subsequently are from Blind et al. (2011) who have developed an approach for the German Institute of Standardization (DIN) that has also been applied to some other OECD countries.

To the extent that TTIP enhances trade which in turn is raising per capita GDP, one gets an indirect innovation effect via the TTIP impact on real per capita GDP. A rise of per capita GDP by $1 \%$ will raise patent applications by $1.8 \%$ - picking up the result from the above model 1. If the TTIP-related per capita GDP increase (as a direct effect of enhanced trade dynamics) is put at about $0.5 \%$ - in line with the Francois et al. study - this would then imply a considerable induced rise of patent applications, namely $0.9 \%$.

As regards the FDI inward variable, a rise of $1 \%$ translates into a rise of patent applications by $0.16 \%$; hence roughly a $6 \%$ rise of the inward FDI stock-GDP ratio would be necessary to bring about a $1 \%$ increase of the patent applications in the EU. If the output elasticity of the patent stock with respect to GDP is assumed to be 0.34 (this is the figure for Germany in Blind et al. 2011, p. 14), a rise of the 
Table 6 Modified Knowledge Production Function (including real R\&D expenditures in euro) for EU20.

Dependent Variable: LOG(PAT?)

Method: Pooled Least Squares.

Date: 01/14/16 Time: 17:26.

Sample: 20022012.

Included observations: 11.

Cross-sections included: 20.

Total pool (unbalanced) observations: 210.

Variable

C

Coefficient
-6.910661
0.574459
0.618048
0.227854

Std. Error

t-Statistic

Prob.

LOG(RDEXPEURO?)

2.126963

$-3.249074$

0.0014

LOG(PGDPEURO?)

0.096928

5.926666

0.0000

LOG(FDISTOCK?)

0.240575

2.569044

0.0110

Fixed Effects (Cross)

$\begin{array}{cr}\text { _AT--C } & 0.392645 \\ \text {-BE--C } & 0.162212 \\ \text {-CZ--C } & -0.219948 \\ \text { _DK--C } & 0.060017 \\ \text {-FI--C } & 0.303319 \\ \text { _FR--C } & 0.550956 \\ \text {-DE--C } & 1.255708 \\ \text {-GR--C } & -0.948358 \\ \text {-HU--C } & 0.315520 \\ \text {-IE--C } & -0.693965 \\ \text {-IT--C } & 0.646938 \\ \text {-LU--C } & -1.145114 \\ \text {-NL-C } & 0.419028 \\ \text {-PL--C } & 0.030470 \\ \text {-PT--C } & -1.256537 \\ \text {-SK--C } & -0.098500 \\ \text {-SI--C } & -0.011108 \\ \text {-ES--C } & -0.329448 \\ \text {-SE--C } & 0.312466 \\ \text { _UK--C } & 0.265825\end{array}$

Fixed Effects (Period)

$\begin{array}{lr}2002--C & 0.006841 \\ 2003--C & 0.098907 \\ 2004--C & 0.125799 \\ 2005--C & 0.081227 \\ 2006--C & 0.074593 \\ 2007--C & 0.014757 \\ 2008--C & -0.030287 \\ 2009--C & -0.051838 \\ 2010--C & -0.109545\end{array}$


Table 6 (continued)

\begin{tabular}{lclr}
\hline 2011-C & -0.106003 & & \\
$2012-\mathrm{C}$ & -0.104449 & & \\
Effects Specification & & & \\
Cross-section fixed (dummy variables) & & \\
Period fixed (dummy variables) & & & 6.705092 \\
R-squared & 0.995383 & Mean dependent var & 1.795074 \\
Adjusted R-squared & 0.994548 & S.D. dependent var & -1.060555 \\
S.E. of regression & 0.132539 & Akaike info criterion & -0.534580 \\
Sum squared resid & 3.109277 & Schwarz criterion & -0.847923 \\
Log likelihood & 144.3582 & Hannan-Quinn criter. & 1.367294 \\
F-statistic & 1192.518 & Durbin-Watson stat & \\
Prob(F-statistic) & 0.000000 & & \\
\hline
\end{tabular}

FDI stock GDP-ratio by $12 \%$ will raise patent applications by $2 \%$ and bring about a rise of real income by $0.67 \%$ through the enhanced patent stock.

An assumed increase of the EU's FDI inward stock-GDP ratio of $12 \%$ will bring another $0.67 \%$ increase of real GDP to which one would have to add another $0.9 \% \times 0.34=0.31 \%$ from the trade-related direct per capita income effect so that the integration related real income gain is $0.5 \%+0.67 \%+0.31 \%=1.48 \%$. TTIP also is concerned with removing non-tariff barriers - e.g. in the form of different technical norms; if TTIP could help to create more common technical norms this also would add to higher GDP. In an econometric study for Germany, Blind et al. (2011) find that the output elasticity of norms is 0.18 which is roughly $1 / 2$ of the elasticity found for patents. If the number of common norms in the EU - and the US - could be increased through TTIP by $2 \%$ the real GDP in Germany (by assumption: similarly in the EU) would increase by $0.36 \%$ This aspect shows how important the reduction of non-tariff barriers actually is; it is well known that the US automotive industry and the EU automotive industry have been able to define considerable common ground in the field of future common norms in the negotiations in the context of the TTIP project so that the automotive industry indeed is a crucial industry for achieving more common transatlantic norms in the future and hence saving costs and raising output, respectively. By contrast the information obtained from leading German representatives of the sector machinery and equipment suggests that the non-uniform US norm system in machinery and equipment makes it rather difficult to define common transatlantic norms for this sector (with German and EU firms typically emphasizing the ISO norm approach). This clearly suggests that considerable efforts should be invested at the industry level to achieve more common transatlantic standards and norms, respectively.

Finally, one has to add to this the long run transatlantic income spillover effect which implies (using standard results from the EU's QUEST model), based on an assumed output increase of $2 \%$ in the US, that an additional $0.2-0.3 \%$ output increase will have to be added which brings the total real income gain so far to $2.1 \%$ for the EU20 countries considered here. 
One may emphasize that the US output effects are unlikely to differ very much from that for the EU since the Francois et al. (2013) figure puts the trade related GDP increase at $0.4 \%$ - only slightly lower than the effect for the EU - and since transatlantic trade-GDP ratios for the EU and the US both stand at about 3\% of GDP while the share of value added represented by European investors in the US was at 3\% in 2012 (according to BEA figures) and that of US subsidiaries at the EU GDP in turn also was about 3\% in 2012. While intermediate input intensity of the EU and the US differ slightly as shown by Welfens and Irawan (2014), there is no reason to assume massive differences of the major benefit elements on both sides of the Atlantic. Moreover, there is a strong positive correlation between the total factor productivity growth of the EU and the US.

As the country dummy for Germany is positive, one may argue that the German population may expect an increase of about $2 \%$ of GDP through TTIP: For Germany this would imply a real income gain of about $€ 60$ billion - if one takes the GDP of 2015 as the point of reference - and with taxes and social security contribution rates standing at a combined $36 \%$, general government will obtain additional revenues of $€$ 22 billion.

\section{BOX}

TTIP Related Economic Benefits for EU Countries: Real Income Effects in Percent

- Trade related per capita income gain (Francois et al. 2013): 0.5 percent

- Induced trade related per capita income gain with transmission to knowledge: 0.31 percent

- $12 \%$ increase of FDI-GDP ratio in EU: 0.67 percent

- $2 \%$ increase of - common - industry norms: 0.36 percent*

- Transatlantic income spillover from US (assumption GDP+ is $2 \%$ ) to EU GDP: 0.25 percent

- Grand Total: $2.09 \%$

* based on Germany's output elasticity (for the EU the effect might be somewhat smaller since the share of industry in Germany is above the EU average)

While US FDI to the EU will increase after conclusion of TTIP, one may also consider that there could be some FDI diversion effects with respect to third countries so that the overall increase of the inward FDI stock-GDP ratio will not necessarily rise by the pure additional FDI inflows from the US. However, as already emphasized, one cannot rule out that not only higher FDI inflows from the US to the EU will be observed but complementary FDI inflows from third countries as well - following an adequately modified logic of tariff jumping here. From a theoretical and empirical perspective the imperfect capital market approach of Froot and Stein (1991) has suggested that the real exchange rate matters for foreign direct investment. If TTIP brings a depreciation of the US Dollar vis-à-vis the Euro and the British Pound, the US would attract higher FDI inflows - relative to GDP - due to the effect that an appreciation of foreign currencies raises equity capital of foreign bidders eager to engage in leveraged international mergers and acquisitions; FDI inflows into the EU would be weakened by the real appreciation of the Euro and the British pound. If, however, there is a Dollar appreciation, the US inflows would be dampened and those 
going to the UK and to the Eurozone would be raised. The exchange rate effects of regional trade integration and FDI dynamics in this context have so far not be considered in theoretical models, but the appendix sheds some light on this issue within a compact two country macro model.

If higher FDI inflows raise the patent application figures, there will be further economic dynamics. Higher patent applications in turn could stimulate more FDI inflows in the long run: Time series analysis for Germany and the UK by Barrell and Pain (1999) in the context of the EU single market dynamics have shown such effects. With respect to TTIP a similar pattern may be expected.

To the extent that TTIP brings enhanced modernization pressure on the supply side of all EU countries and the US, Germany's machinery and equipment export sector stands to have additional structural benefits which could further raise the real income effect for Germany so that about $2 \%$ seems to be a realistic order of magnitude. This also takes into account that the fixed country effects indicated that Germany stands to have above average innovation impacts in the cross country analysis shown here. For Germany, 2\% of GDP implies an increase of about $€ 60$ billion - based on a GDP of about $€ 3000$ billion; the rise of the Eurozone real income would be about $€ 200$ billion and for the EU an estimated rise of $€ 280$ billion is an adequate figure. In an endogenous growth modeling perspective, the findings from the knowledge production function regressions suggest that TTIP could indeed generate considerable benefits for the EU countries in general and for Germany in particular.

Beyond the familiar trade effects, the indirect effects from foreign direct investment inflows and induced innovation effects should be considered. Thus the expected TTIP benefits for the EU countries are certainly larger than the CEPR study of Francois et al. (2013) has suggested. The regression analysis has shown that FDI stocks affect patent dynamics in EU countries and this TTIP-relevant channel should certainly not be neglected. The incentive to engage in more $\mathrm{R} \& \mathrm{D}$ aiming at obtaining more patents and first mover advantages in the international innovation race could be reinforced by TTIP through the expansionary impulse that TTIP has on intra-industrial trade; here one may expect, of course, trade creation, but at the same time the enhanced transatlantic competition and the falling rate of return on equity lets one expect that firms in countries with an advanced innovation system in Europe will show a Schumpeterian innovation response. This Schumpeterian product innovation response should indeed be strong both in the EU and in the US and the presence of US investors in the EU suggests that there will be transatlantic spillover effects as well; there should be a mirror mechanism in the US in which EU subsidiaries in certain sectors could also benefit from regional innovation spillovers and hence from higher R\&D-sales ratios of major US competitors.

While the NAFTA project has largely been one that brought together two advanced economies with high endowments of capital and knowledge in the US and Canada plus Mexico's rich endowment of labor relative to capital and knowledge, TTIP would be the first regional integration approach in which two countries with very similar endowments of production factors meet: both the US and the EU are richly endowed with capital and knowledge - both have a high human capital intensity. One thus may expect that the skilled labor wage premium in both the EU and the US will fall transitorily, however, the expansion of multinational companies investments on both 
sides of the Atlantic and the enhanced innovation race is likely to raise the long run demand for skilled labor so that the long run effect should be a rise of the skilled labor premium (the ratio skilled workers' wages to unskilled workers' wages). These and other implications could be studied within research extensions that would be useful for both the United States and the European Union. A broader analysis of transatlantic adjustment effects in the context of TTIP requires, of course, careful simulation analysis and key findings from various research groups (Welfens, Korus and Irawan 2014) suggest that both the EU and the US will benefit while outsider countries might face a real income decline; since the share of intermediate products of EU firms (producing in the European Union) is higher than that of US firms - producing in the United States more third country partner firms of EU producers may be expected to benefit from the integration into the European value-added chain than industrial suppliers of US firms. Evaluating the economic benefit of TTIP requires to some extent to focus not only on GDP effects but rather on the effects on real national income. With cumulated inward FDI and cumulated outward FDI there will be dividends obtained from subsidiaries and part of profits obtained by subsidiaries from abroad will be transferred to the headquarter abroad.

Third countries are likely to benefit from TTIP in the long run if the combined EUUS output effect is rather large and if TTIP negotiations should bring about rules of origin that help suppliers from developing countries to benefit from TTIP induced economic dynamics in the US and the EU. The EU and the US might consider to help firms from developing countries to achieve the enhanced standards that are likely to emerge in the context of TTIP in the combined area EU + USA (trilateral initiatives might even be useful here: e.g. the German GIZ organization plus USAID could team up to help firms from developing countries to achieve the new more ambitious standards in a TTIP-based transatlantic integrated market). It should not be too difficult to achieve a global win-win-win situation on the basis of carefully designed new cooperation approaches. The critics of TTIP in Germany and other EU countries have long argued that TTIP brings small benefits and is detrimental to developing countries, but this argument is not really convincing if one takes into account the new findings of FDI related and innovation based extra benefits under TTIP.

At the bottom line one may also recommend that governments in the US and in EU countries will take a careful look at innovation spillovers - if TTIP leads to intensified innovation spillovers within the EU (or the US) it would be adequate that government raises $R \& D$ subsidies in order to internalize such additional spillovers. The fact that the R\&D-GDP ratio of the EU is clearly lower than that of the US could be a starting point to once more take a critical view on innovation dynamics in the European Union. Secondly, the transatlantic R\&D-GDP gap might suggest that TTIP-induced dynamics will help EU countries to catch up technologically with the United States. Since US subsidiaries stand for about $3 \%$ of overall value-added in Europe it is clear that there are special opportunities for the US to indirectly benefit from enhanced innovation and growth dynamics in Europe. At the same time, the fact that European firms' subsidiaries stand for about $3 \%$ of US GDP implies that European subsidiaries in the US are well positioned to benefit from a further rise of US R\&D-expenditures in the United in the context of TTIP. Whether or not TTIP will enhance techno-globalization, as a rather new phenomenon (Jungmittag 2016) that stands for more international joint R\&D 
projects as well as for the international outsourcing and offshoring of part of the R\&D process in leading OECD countries, will have to be seen.

The time series analysis for Germany shows that there is a long run impact of FDI on innovation and that there is a link between innovation and output growth. There is no direct link between the FDI-GDP ratio and output growth. As regards the link between patent applications and the trend FDI-output ratio, there is a significant impact: Higher FDI raises patent levels and higher patents stimulate output. While one cannot be sure that the links are the same for the other EU countries, one may point out that Germany stands for $25 \%$ of the EU's GDP and the regional splitting up of value-added chains of Germany companies in the EU imply that other EU countries will have positive output effects from the supply side as well; demand side effects related to higher exports could also be crucial. Further research could look into similar questions for France, the UK, Italy, the Netherlands, Belgium and Spain as well as other EU countries. The knowledge production function can also be applied to China or the US if one applies this approach with respect to the 31 regions of China and the 50 US states or the 16 federal states/regions in Germany.

\section{FDI patent output Nexus for Germany}

In the following, we used the bounds testing approach of Pesaran/Shin/Smith (2001) to analyze the relationships between FDI to GDP ratio, patent applications at the European Patent Office (EPO) and GDP growth for Germany in the period from 1991 to 2014. Looking at this period means that we avoid any Brexit-related economic and political dynamics in the EU countries and Germany, respectively. Brexit implies many new economic challenges (Welfens 2017) and there is also is no doubt that Brexit will have a strong impact on the UK's FDI inflows and FDI outflows (Welfens and Baier 2018) which naturally would partly affect Germany and other EU partner countries of the United Kingdom. Germany would account for close to $25 \%$ of EU27 GDP postBrexit and in 2019 it represented almost $30 \%$ of the Eurozone's GDP.

The FDI to GDP ratio is calculated as the trend development of the net inflows of FDI (equity capital) to GDP ratio (FDI_TRENDQ). PAT_TOT are the total German patent applications at the EPO. Furthermore, we differentiated between patents owned solely by German residents (PAT_DOM) and patent applications owned partly or completely by foreigners (PAT_FOW). Finally, WBIP is the growth rate of real GDP in percent.

The detailed results are shown in the following tables. Of special interest are the long-run coefficients in the cointegration equations calculated from the autoregressive distributed lag (ARDL) models. They show, on the one hand, the long-run impact of an increase of the trend FDI to GDP ratio on the patent applications and, on the other hand, of the patent applications on GDP growth.

ARDL Cointegrating And Long Run Form.

Dependent Variable: LOG(PAT_TOT).

Selected Model: ARDL(3, 4).

Date: 12/13/15 Time: 18:43. 
Sample: 19912014.

Included observations: 18 .

Cointegrating Form

Variable

Coefficient

Std. Error

t-Statistic

Prob.

DLOG(PAT_TOT(-1))

$0.380421 \quad 0.209324$

1.817379

0.1025

DLOG(PAT_TOT(-2))

0.352503

0.227223

1.551349

0.1552

D(FDI_TRENDQ)

$-0.564981$

0.235094

$-2.403218$

0.0397

D(FDI_TRENDQ(-1))

0.432614

0.403103

1.073209

0.3111

D(FDI_TRENDQ(-2))

0.280669

0.418241

0.671071

0.5190

D(FDI_TRENDQ(-3))

$-0.607450$

0.291035

$-2.087204$

0.0665

CointEq(-1)

$-0.393621$

0.109569

0.0058

Cointeq $=$ LOG $($ PAT_TOT $)-(0.2114 *$ FDI_TRENDQ +9.8180$)$

Long Run Coefficients

$\begin{array}{ccccc}\text { Variable } & \text { Coefficient } & \text { Std. Error } & \text { t-Statistic } & \text { Prob. } \\ \text { FDI_TRENDQ } & 0.211412 & 0.124799 & 1.694012 & 0.1245 \\ \text { C } & 9.818013 & 0.109821 & 89.399843 & 0.0000\end{array}$

ARDL Cointegrating And Long Run Form.

Dependent Variable: LOG(PAT_FOW).

Selected Model: ARDL $(1,0)$.

Date: 12/13/15 Time: 18:42.

Sample: 19912014.

Included observations: 21.

Cointegrating Form

$\begin{array}{ccccc}\text { Variable } & \text { Coefficient } & \text { Std. Error } & \text { t-Statistic } & \text { Prob. } \\ \text { D(FDI_TRENDQ) } & 0.100220 & 0.085669 & 1.169852 & 0.2573 \\ \text { CointEq(-1) } & -0.163985 & 0.026844 & -6.108744 & 0.0000\end{array}$

Cointeq $=$ LOG(PAT_FOW $)-(0.7796 *$ FDI_TRENDQ + 7.5964)

Long Run Coefficients

\begin{tabular}{ccccc} 
Variable & Coefficient & Std. Error & t-Statistic & Prob. \\
FDI_TRENDQ & 0.779587 & 0.135097 & 5.770584 & 0.0000 \\
C & 7.596391 & 0.147449 & 51.518666 & 0.0000 \\
\hline
\end{tabular}

ARDL Cointegrating And Long Run Form.

Dependent Variable: LOG(PAT_DOM).

Selected Model: ARDL(3, 4).

Date: 12/13/15 Time: 18:39.

Sample: 19912014.

Included observations: 18.

Cointegrating Form

Variable

DLOG(PAT_DOM(-1))

DLOG(PAT_DOM(-2))

Coefficient
0.428916
0.349017

Std. Error

0.202565

0.228239
t-Statistic

Prob.

2.117426

0.0633

1.529172

0.1606 


\begin{tabular}{ccccc}
\hline D(FDI_TRENDQ) & -0.604663 & 0.218966 & -2.761447 & 0.0221 \\
D(FDI_TRENDQ $(-1))$ & 0.552578 & 0.378729 & 1.459032 & 0.1786 \\
D(FDI_TRENDQ(-2)) & 0.219288 & 0.410018 & 0.534826 & 0.6057 \\
D(FDI_TRENDQ(-3)) & -0.596437 & 0.280159 & -2.128923 & 0.0621 \\
CointEq(-1) & -0.406363 & 0.108579 & -3.742550 & 0.0046 \\
Cointeq = LOG(PAT_DOM) & $(0.1923 *$ FDI_TRENDQ & $+9.6631)$ & & \\
Long Run Coefficients & & & \\
$\quad$ Variable & Coefficient & Std. Error & t-Statistic & Prob. \\
FDI_TRENDQ & 0.192282 & 0.111591 & 1.723097 & 0.1190 \\
C & 9.663079 & 0.100006 & 96.624793 & 0.0000 \\
\hline
\end{tabular}

ARDL Cointegrating And Long Run Form.

Dependent Variable: WBIP.

Selected Model: $\operatorname{ARDL}(3,1)$.

Date: 12/14/15 Time: 11:20.

Sample: 19912014.

Included observations: 18.

Cointegrating Form

$\begin{array}{ccccc}\text { Variable } & \text { Coefficient } & \text { Std. Error } & \text { t-Statistic } & \text { Prob. } \\ \text { D(WBIP(-1)) } & 0.870345 & 0.264296 & 3.293070 & 0.0064 \\ \text { D(WBIP(-2)) } & 0.442853 & 0.190262 & 2.327596 & 0.0382 \\ \text { DLOG(PAT_TOT) } & 29.968469 & 5.803115 & 5.164203 & 0.0002 \\ \text { CointEq(-1) } & -2.064178 & 0.349165 & -5.911749 & 0.0001\end{array}$

Cointeq = WBIP - (1.9864*LOG(PAT_TOT) -19.0533$)$

Long Run Coefficients

$\begin{array}{ccccc}\text { Variable } & \text { Coefficient } & \text { Std. Error } & \text { t-Statistic } & \text { Prob. } \\ \text { LOG(PAT_TOT) } & 1.986431 & 1.166087 & 1.703502 & 0.1142 \\ \text { C } & -19.053337 & 11.786939 & -1.616479 & 0.1320\end{array}$

ARDL Cointegrating And Long Run Form.

Dependent Variable: WBIP.

Selected Model: ARDL $(3,0)$.

Date: 12/14/15 Time: 11:34.

Sample: 19912014.

Included observations: 18.

Cointegrating Form

$\begin{array}{ccccc}\text { Variable } & \text { Coefficient } & \text { Std. Error } & \text { t-Statistic } & \text { Prob. } \\ \text { D(WBIP(-1)) } & 0.852022 & 0.318306 & 2.676739 & 0.0190 \\ \text { D(WBIP(-2)) } & 0.416746 & 0.219792 & 1.896088 & 0.0804 \\ \text { DLOG(PAT_TOT, 2) } & 19.717012 & 9.355590 & 2.107511 & 0.0551 \\ \text { CointEq(-1) } & -2.034773 & 0.509069 & -3.997046 & 0.0015\end{array}$

Cointeq $=$ WBIP $-(8.2407 *$ DLOG $($ PAT_TOT $)+0.9878)$

Long Run Coefficients 


\begin{tabular}{ccccc}
\hline Variable & Coefficient & Std. Error & t-Statistic & Prob. \\
DLOG(PAT_TOT) & 8.240707 & 3.760163 & 2.191582 & 0.0472 \\
C & 0.987787 & 0.243031 & 4.064447 & 0.0013 \\
\hline
\end{tabular}

In a nutshell, the key findings from the regression analysis for Germany on the FDIpatent-output nexus are as follows (based on the net inflow FDI-GDP ratio which had an average value of $0.84 \%$ - with a minimum of $-0.39 \%$ and a maximum of $1.51 \%$ ):

- There is no direct link between the FDI-GDP ratio and output growth.

- As regards the link between patent applications and the trend FDI-output ratio, there is a significant impact: Using the long run coefficient, a rise of the trend FDI-GDP ratio by 0.1 percentage points will raise patent applications by $2.1 \%$. If one makes a distinction between patents owned (or co-owned) by foreigners and patents of domestic residents, a rise of the trend FDI-GDP ratio by 0.1 percentage points will raise the former by $7.8 \%$ and the latter by $1.9 \%$.

The long run relation between output growth and patent applications is also considered: If one assumes a rise of patent applications by $2.1 \%$, the long run link between GDP growth and the level of patent applications (in logs) suggests a contribution of output growth of 0.042 percentage points while the long run link between output growth and first differences of patent applications (again in logs) suggests an output contribution of 0.17 percentage points. Thus a rise of the trend FDI to GDP ratio by 0.6 percentage points would indirectly lead to an output increase of 1 percentage point for Germany. This finding does not include any international macroeconomic spillover effects from Germany/the EU (one may assume that the EU effects would be rather similar to those for Germany) to the US and relevant feedbacks to Germany/the EU which should stimulate transatlantic trade dynamics beyond the $1 \%$ output effect of Germany/the EU.

\section{Implications and policy conclusions}

The study presented gives a theoretical framework for an open economy knowledge production function and it is the first empirical analysis of EU20 countries with respect to FDI and innovation dynamics; this then is the natural analytical framework for understanding the Schumpeterian TTIP benefits that can be expected in the long run. These Schumpeterian benefits are higher than the pure trade creation effects analyzed by Francois et al. (2013). For deep integration schemes such a complementary Schumpeterian analysis is indispensable. One cannot rule that a populist US government - with close links to Wall Street banks and major US multinational companies (e.g. through financial donations to the Republican Party) - would, in a new TTIP project, put more emphasis on the FDI-related aspects than previous US Administrations dealing with US-EU liberalization perspectives; both trade and FDI aspects could be highly relevant where an additional twist could be that higher US FDI stocks in the EU would trigger additional net exports of the US to the European Union - if this were the case, the Trumpian emphasis on reducing the US trade balance deficits and the US current account deficit would play a role in US considerations. The two balances are, 
however, rather distinct concepts and it is rather confusing that the Trump Administration has publicly put so much emphasis on the US trade balance deficit. The pure effect of higher US FDI stocks in the EU in a TTIP environment would clearly reduce the US current deficit through higher US subsidiaries' profits accruing from Europe; while the EU firms will also have higher FDI stocks in the US in a new TTIP environment, the net profit balance effect should be in favor of the US (possibly except for the case of Brexit).

The analysis presented suggests that an intensified Schumpeterian competition in two leading global open economies, namely the EU and the US, will bring about major economic benefits in the context of TTIP (possibly renamed by a populist US Administration). Higher foreign direct investment is a crucial element of these benefits which have to be added to the traditionally trade-related welfare analysis. Foreign direct investment can be expected to rise relative to GDP once TTIP brings about a reduction of transatlantic investment barriers and once the enhanced transatlantic intra-industrial trade stimulates firms in both the US and the EU to become more engaged in research and development and hence in multinational innovation dynamics. As regards the EU, one may expect considerable additional benefits from higher innovation dynamics and a higher level of patent applications. The empirical findings for the knowledge production function for 20 EU countries has clearly shown evidence that more researchers, a higher FDI inward stock-GDP ratio and a higher per capita income - itself raised by the trade creation effects of TTIP - will raise patent applications. These in turn will raise the production potential and long run real GDP, respectively. The estimation derived for the EU is a benefit of about $2 \%$ of GDP in this Schumpeterian perspective of TTIP which is four times the figure of the Francois et al. (2013) study for the European Commission; this study was, however, related largely to trade aspects - this is too narrow a view on a deep integration project such as TTIP. It should also be emphasized that the study presented here is much in contrast to the study of IFO (2013a) that has argued that TTIP would raise US output by $13.4 \%$ and Germany's output by $4.7 \%$ - these figures are highly implausible as benefits implied from transatlantic trade liberalization seem to be too high.

From a policy perspective, the enlarged integrated transatlantic markets will stimulate the creation of bigger firms, particularly multinational companies, so that one may anticipate more international mergers and acquisitions - plus some additional greenfield investments by MNCs in the US and the EU, respectively. The competitionenhancing effects of TTIP that are crucial for more Schumpeterian dynamics and hence innovation related economic welfare gains could be endangered if the degree of competition falls below a critical level. From this perspective, it is quite important that stronger transatlantic cooperation between the US and the EU in the field of competition policy will be organized. So far this topic has not been addressed in a transatlantic economic policy dialogue.

As regards Germany, France, the UK and many other EU countries, there is also a considerable challenge in the field of raising the share of skilled workers. The expansion of foreign direct investment and innovation dynamics, respectively, will raise the demand for skilled labor. While it is true that the short-term effect of TTIP brings together two countries that are richly endowed with human capital, so that the skilled labor premium will decline transitorily, it is obvious that the long run 
Schumpeterian dynamics of TTIP will raise the relative labor demand for skilled labor - here the conclusion is in contrast to the IFO (2013b) analysis that has emphasized that the wage ratio of unskilled labor/skilled labor will increase.

The high relevance of FDI inflows for Europe - and their role on innovation dynamics - suggests that EU countries' governments should take a closer look at the national innovation system while the European Commission would be wise to consider crucial aspects of cooperation, EU budget priorities and prospects for regional innovation spillovers. There is a broad literature on regional knowledge production functions and also crucial results with respect to Europe and the US. The European Commission would be wise to encourage member countries to modernize their respective national innovation systems and to increase their attractiveness with respect to foreign direct investment inflows. Moreover, the EU's structural funds could get a more proinnovation direction.

It should not be difficult to integrate some key aspects of TTIP into the QUEST model and to get additional insights on the macroeconomic medium term effects of the TTIP project. The macroeconomic transatlantic spillover effects should not be neglected in the analysis and it is also clear that taking into account the overall real income effects of TTIP there will be trade creating effects for third countries.

While the Trump Administration has considerable reservations with respect to trade liberalization with relatively poor countries - including Asian countries in the TTP project now renounced by the new administration - the US seems to be rather willing to reconsider the prospects for a partial or full trade liberalization with the EU28. If Brexit is indeed completed in 2019, the US and the UK can be expected to quickly adopt a free trade agreement; the British government, facing declining growth rates of real gross national income in the context of Brexit will hardly be in a position to push the US for major concession in critical fields. Whether or not the US is willing to consider a "new TTIP" with the EU27 remains to be seen. The general agreement in the EU-Japan trade liberalization achieved in the week before the G20 meeting in Hamburg in July 2017 adds some pressure to reconsider US-EU liberalization talks even though Mr. Trump has emphasized a preference for bilateralism; the Trump Administration has also repeatedly criticized the German government for its high current account deficit-GDP ratio which reached $8.5 \%$ of Germany's GDP in 2016. The latter point is somewhat doubtful since a critical look at the current account position of the Eurozone is economically more meaningful than simply picking out Germany. By reconsidering the US-EU trade liberalization negotiations, the Trump Administration would reinforce the traditional element of multilateralism as a complementary element of US foreign policy. The Trump Administration has created the impression that the WTO and the Bank for International Settlements are institutions that will no longer be actively supported by the US. This in turn undermines multilateralism. For its part, the EU has also weakened the system of international organizations by strongly pushing the IMF to stabilize the Eurozone and Greece, respectively - as regards the latter country not in line with basic IMF rules itself. The IMF has been dominated by the EU and the Eurozone countries, respectively, to such an extent, that many developing countries have raised doubts about this major global international organization which since the start of the Euro crisis in 2010 has become a major actor in co-funding rescue 
packages for Greece. Germany and France seem to be two influential Eurozone countries that have pushed the IMF into remaining on board in terms of several rescue packages for Greece and other countries. The IMF has indicated that the progress of Greek economic reform is rather doubtful and that another debt cut will be needed which, however, is not supported by the German government. There are some indications that at the board level in the IMF the US shares part of the developing countries' objections against an unrealistic Greek consolidation strategy and this in turn reinforces the weakness of the international organization triangle WTO-BIS-IMF (it is strange that the issue of Greek constitutional reform has not been put on the policy agenda by the EU countries although it seems obvious that constitutional reforms are crucial to kick-starting a broader institutional and political modernization process in Greece).

It seems, therefore, that Germany and the EU, respectively, will have to revise their traditional policy on Greece, otherwise the IMF cannot play its crucial role as a global actor for policy monitoring and as an emergency lending authority for countries with sharply worsening current accounts. Only if the roles of the IMF, the BIS and indeed the WTO are restored, could one expect that the economic globalization process could be resumed. A new TTIP initiative could then be a crucial follow-up project supported by the US Administration and the EU (and Germany plus France in particular). Incidentally, the rather skeptical view of the German public on TTIP in 2016 was largely due to Germany's public TV channels which have shown an enormous anti-TTIP bias despite the fact that public broadcasters are expected to present a balanced view on the key arguments on TTIP and similar issues. However, as most journalists seem to fear that TTIP would bring a further narrowing of public broadcasting activities - following an earlier limitation of public TV activities in the context of an EU court verdict regarding public broadcasting in the EU single market - there is a silent and broad anti-TTP push from public television broadcasters. This topic has thus far not been discussed in Germany and the EU although it is a key element of anti-TTIP activism in the EU's largest economy; strangely, the critical conflict of interests in the public television broadcasters of Germany has never been discussed in public (while one could hear from politicians in Berlin that raising the issue of such problem with public TV stations was not really appropriate as national elections lay ahead in 2017 and here full access to such TV stations was crucially important). It remains to be seen how the new TTIP debate will unfold in a transatlantic perspective in 2018 and 2019 which is a crucial year for the EU27, particularly if the UK should quickly get a US-UK trade liberalization package after Brexit.

TTIP-related output expansion effects of about $2 \%$ for Germany and the EU, respectively, could bring a growth of employment of about $1 \%$ in Europe if one assumes that labor productivity will be raised by a full percentage point above the baseline scenario. Such improvements would be in line with the Francois et al. (2013) analysis and the relevant chapter 6 of that report in particular. One could assume that employment effects plus output effects would be even bigger if governments in the US and in EU countries would invest more in training/ retraining which in Europe at least would be a rather natural element of a deep 
integration project. It has been shown (Fouarge et al. 2010) that the willingness of employers to train lower-educated workers is not different from the willingness to retrain skilled workers. However, a frequent problem with unskilled workers is a lack of motivation so that countries in the EU, as well as states in the US, could consider private public partnerships for encouraging innovative retraining schemes for unskilled workers. Such an approach could even be an attractive option for the Trump administration whose interest in maintaining the political support of unskilled workers is quite obvious. As regards the private and social return to higher education, one may emphasize that there are considerable differences across EU countries and within some countries (de la Fuente 2011).

After 2017 a new TTIP approach might be possible depending on the Trump administration. In EU countries as well as in the US TTIP would lead to a higher demand for skilled workers once transatlantic FDI will increase. The initial effect of TTIP, namely to combine two countries with a relative abundance in skilled labor in a transatlantic free trade area, will be to reduce the skilled labor premium in both the US and the EU since both countries are relatively richly endowed with skilled labor. From this perspective, trade unions' natural interest - if they emphasize the short term - should be in favor of TTIP. However, the more long-term adjustment dynamics will be to have a higher capital intensity due to higher foreign direct investment flows; indeed, those economies where the R\&D capital stock per worker is relatively high and therefore also the long-term demand for skilled workers will dominate the EU in the context of TTIP.

One should not rule out that a populist US Administration would consider a new approach for broader transatlantic trade liberalization only after the next major US recession. Often it is only new political pressure for raising output growth that makes politicians - once tax reduction options and deregulation policies have been exhausted as easy political pro-growth measures - consider the rather complex challenge of new international trade treaties. Since President Trump has already given up on the Trans-Pacific Partnership agreement in 2017 and since in TPP the US benefits would be rather modest, the neglected TTIP opportunities might come to the political forefront once againagain; it is noteworthy that President Trump has mentioned US interest in a transatlantic free trade agreement in his speech at the Davos Summit in January 2020. The future political equation under a Republican president might, however, be more difficult than if the president would be from the Democratic Party while the US Senate/ the US Congress is dominated by the Republicans - with the latter typically standing for a free trade attitude in US history. One may also emphasize that the aggressive US trade policy vis-à-vis China has not yielded clear economic benefits for the US as, for example, research by Deutsche Bundesbank (2020) has shown. Moreover, the traditional models of tariff protectionism do not take into account the role of outward foreign direct investment (FDI). It is straightforward to show that US subsidiaries abroad - in China - will face negative consequences of US import tariff protectionism which translates not only into lower US imports from China, but also into an output dampening effect abroad and both effects imply lower profits of subsidiaries abroad so that the traditional 
argument of import protection through tariffs in the case of a big economy, namely lowering the world market offer price (net of import tariffs) is not simply a redistribution of the profits of foreign firms in favor of tariff revenue in the importing country: rather, part of subsidiaries' profits abroad are eliminated so that already an enhanced partial equilibrium model of tariffs and outward FDI (Welfens, 2019, p. 327) suggests that import tariffs could generate very low welfare benefits for the country imposing the tariffs. Trump's protectionist trade policy approach vis-à-vis China - and part of Europe - might bring additional US FDI inflows from Eurozone firms, for example, which anticipate the threat of higher future US import tariffs so that a specific form of tariff-jumping could occur. However, this additional US FDI inflow effectively stands for distorted global production and hence economic welfare losses and negative income effects abroad; any output dampening abroad will in turn reduce US export growth which dampens US GDP growth. A third-best trade policy of the US Administration is not in the interests of US voters who sooner or later will be interested in reconsidering the options for a transatlantic free trade agreement indeed, following the setup of TTIP, in the form of a combination of trade liberalization and transatlantic FDI liberalization.

Acknowledgments We are grateful to seminar participants at the IMF (June 28, 2016), the Congressional Research Service (June 27, 2016) and at the Chinese Academy of Sciences, Beijing (March 24, 2016). Moreover, discussions with Werner Roeger, European Commission are appreciated. Encouragement of Timothy Lane, Bank of Canada, is appreciated; previous discussions on TTIP with Robert Lawrence at the Kennedy School, Harvard University, also are appreciated by Paul Welfens. The authors gratefully acknowledge research support and technical editing advice from Arthur Korus and David Hanrahan, European Institute for International Economic Relations (EIIW). Paul Welfens also acknowledges discussions with Fabian Baier (EIIW) in 2019. The usual disclaimer applies.

Funding Information Open Access funding provided by Projekt DEAL.

\section{Appendix 1: Considerations in the context of making a distinction between expansion of GNP and GDP}

Much of the standard arguments about the pros and cons of TTIP are stated within the framework of looking at the effects of GDP in the EU and the US, respectively. To the extent that GDP is perhaps less interesting than the real gross national product, one has indeed to look at the question of EU economic benefits not simply from a European perspective but has to include the US economic dynamics explicitly. This can be easily seen from the subsequent definition of national income $(Z)$ which, of course, is composed of real GDP (Y) and an element of foreign GDP (see Eqs. 4' and 5'): net profits obtained from abroad become a crucial element of analysis in a world with inward FDI and outward FDI. It should be noted that the real exchange rate also plays a role so that, for example, a real depreciation of the Euro will raise the real national income of people in the euro zone.

Moreover, theoretical aspects of international macroeconomic interdependence in the context of both trade and foreign direct investment are crucial and in the 
literature FDI typically is neglected although the critical distinction between gross domestic product and gross national income is of key importance: Consumption, imports and exports should naturally be assumed to be proportionate to real income $(\mathrm{Z})$ and not to gross domestic product $(\mathrm{Y})$. Hence a transatlantic macro perspective should clearly put the analytical focus on the relevant economic categories. One should point out that in a demand-determined income framework the adequate theoretical macro perspective on the transatlantic economic interdependence is partly linked to real gross national income in the EU and the US, and not as much on real gross GDP which has already been emphasized by WELFENS (2011) where the distinction between GDP and GNP is considered in the simple framework of Cobb-Douglas production functions plus competition in goods and factor markets. Assuming a Cobb-Douglas production function in each of the two countries considered, namely $\mathrm{Y}=\mathrm{K}^{\beta}(\mathrm{AL})^{1-\beta}$ in the home country (country 1 ) and $\mathrm{Y}^{*}=\mathrm{K}^{*} \beta^{*}\left(\mathrm{~A}^{*} \mathrm{~L}^{*}\right)^{1-\beta^{*}}$ in country 2 (* denoting foreign variables), we can write for $Z$ and $Z^{*}$, respectively ( $\alpha$ denoting the share of capital owned by foreign investors in country $2 ; \alpha^{*}$ denoting the share of capital owned by foreign investors in country 1 ; and $\mathrm{q}^{*}:=\mathrm{eP}^{*} / \mathrm{P}$ where $\mathrm{e}$ is the nominal exchange and $\mathrm{P}$ the price level):

$$
\begin{gathered}
Z=Y\left(1-\alpha^{*} \beta\right)+\alpha \beta^{*} Y^{*} q^{*} \\
Z^{*}=Y^{*}\left(1-\alpha \beta^{*}\right)+\alpha^{*} \beta Y / q^{*}
\end{gathered}
$$

Here gross national income is Y plus real net profit transfers from abroad - profits of country 2 subsidiaries amount to $\alpha * \beta Y$ in country 1 provided there is competition in goods and factor markets. Considering goods market equilibrium conditions in the home country and the foreign country - while assuming a specific investment function (with net investment $\mathrm{I}=\mathrm{br}+\mathrm{b}^{\prime}\left(\beta \mathrm{Y} / \mathrm{K}-\beta^{*} \mathrm{Y}^{*} / \mathrm{K}^{*}\right)$ plus other terms; $\mathrm{b}$ and $b^{\prime}$ are positive parameters) and that real consumption $\mathrm{C}$ and real imports $\mathrm{J}$ are proportionate to real income in both countries and that exports $\mathrm{X}$ are proportionate to foreign real income - not to GDP as many standard models suggest - we get a new equation for international economic interdependency in a world with multinational companies as can be derived fairly easily. If one covers the intensity of trade by the export-GDP ratio $\mathrm{X} / \mathrm{Y}:=\mathrm{x}$ and the import-GDP ratio $\mathrm{q}^{*} \mathrm{~J} / \mathrm{Y}:=\mathrm{j}-$ with $\mathrm{X}$ and $\mathrm{J}$ denoting real exports and $\mathrm{q}^{*}$ the real exchange rate - one can understand that the international output multipliers $d \mathrm{Y} / \mathrm{dY}^{*}$ and $\mathrm{dY} * / \mathrm{dY}$ for the case of two large economies are influenced both by trade intensity and the FDI globalization indicators $\alpha$ and $\alpha^{*}$. To the extent that regional trade integration is coupled with a decline of international capital flows - and also taking into account some theoretical aspects of links between trade and FDI dynamics as well as innovation dynamics - a demand-determined medium term international output multiplier is important for understanding TTIP or TPP. In addition to a medium term approach a long term macro modeling is required which reflects a growth approach in an open economy with FDI. 
Open Access This article is licensed under a Creative Commons Attribution 4.0 International License, which permits use, sharing, adaptation, distribution and reproduction in any medium or format, as long as you give appropriate credit to the original author(s) and the source, provide a link to the Creative Commons licence, and indicate if changes were made. The images or other third party material in this article are included in the article's Creative Commons licence, unless indicated otherwise in a credit line to the material. If material is not included in the article's Creative Commons licence and your intended use is not permitted by statutory regulation or exceeds the permitted use, you will need to obtain permission directly from the copyright holder. To view a copy of this licence, visit http://creativecommons.org/licenses/by/4.0/.

\section{References}

Abdih Y, Joutz F (2005) Relating the knowledge production function to Total factor productivity: an endogenous growth puzzle. IMF Working Paper 05/74, International Monetary Fund, Washington DC

Antonietti R, Bronzini R, Cainelli G (2015) Inward foreign direct investment and innovation: evidence from Italian provinces. Working Paper No. 1006, Banca d'Italia, Rome

Asian Development Bank (2015) Asian economic integration report: how can special economic zones catalyze economic development? Asian Development Bank, Manila

Atkeson A, Burstein A (2008) Pricing-to-market, trade costs, and international relative prices. Am Econ Rev 98:1998-2031. https://doi.org/10.1257/aer.98.5.1998

Barrell R, Pain N (1999) Domestic institutions, agglomerations and foreign direct investment in Europe. Eur Econ Rev 43:925-934. https://doi.org/10.1016/S0014-2921(98)00105-6

Blind K, Jungmittag A (2008) The impact of patents and standards on macroeconomic growth: a panel approach covering four countries and 12 sectors. J Prod Anal 29:51-60. https://doi.org/10.1007/s11123-007-0060-8

Blind K, Jungmittag A, Mangelsdorf A (2011) Der gesamtwirtschaftliche Nutzen der Normung (The Economic Benefits of Standardization). German Institute for Standardization (DIN)

Bottazzi L, Peri G (2003) Innovation and spillovers in regions: Evidence from European patent data. Eur Econ Rev 47:687-710. https://doi.org/10.1016/S0014-2921(02)00307-0

Charlot S, Crescenzi R, Musolesi A (2014) Econometric modelling of the regional production function in Europe. J Econ Geogr 15:1227-1259. https://doi.org/10.1093/jeg/lbu035

Cheung K, Lin P (2004) Spillover effects of FDI on innovation in China: evidence from the provincial data. China Econ Rev 15:25-44. https://doi.org/10.1016/S1043-951X(03)00027-0

Coe DT, Helpman E (1995) International R\&D spillovers. Eur Econ Rev 39:859-887. https://doi.org/10.1016 /0014-2921(94)00100-E

De La Fuente A (2011) Human capital and productivity. Nord Econ Policy Rev 2:103-131

Deutsche Bundesbank (2020), Folgen des zunehmenden Protectionismus (Consequences of Rising Protectionism), Monatsberichte der Deutschen Bundesbank/Monthly Report of Deutsche Bundesbank, January, 49-71.

Dunning JH (1977) Trade, location of economic activity and the MNE: A search for an eclectic approach. In: Ohlin B, Hesselborn PO, Wijkman PM (eds) The international allocation of economic activity. Palgrave Macmillan, London. https://doi.org/10.1007/978-1-349-03196-2_38

Edmond C, Midrigan V, Xu DY (2015) Competition, Markups, and the Gains from International Trade. Am Econ Rev 105:3183-3221. https://doi.org/10.1257/aer.20120549

Felbermayr G (2019) Trump hat dem Welthandel bisher nicht geschadet. Reporting by Bernau P, Brankovic M, Obertreis S, and Záboji N. Frankfurter Allgemeine, Wirtschaft, Der Handelstreit, updated on 11 December 2019 https://www.faz.net/aktuell/wirtschaft/der-handelsstreit/gabriel-felbermayr-ueber-dennutzen-von-zoellen-und-donald-trump-16524134.html last accessed 18.12.2019

Fouarge D, Schils T, de Grip A (2010) Why do low-educated workers invest less in further training. IZA discussion paper series, IZA DP No. 5180, September 2010

Francois J et al (2013) Reducing transatlantic barriers to trade and investment. CEPR (for the European Commission): London

Fritsch M (2002) Measuring the quality of regional innovation systems: a knowledge production function approach. Int Reg Sci Rev 25(1):86-101. https://doi.org/10.1177/016001702762039394

Froot KA, Stein JC (1991) Exchange rates and foreign direct investment: an imperfect capital markets approach. Q J Econ 106:1191-1217. https://doi.org/10.2307/2937961 
Griliches Z (1979) Issues in Assessing the Contribution of Research and Development to Productivity Growth. Bell J Econ 10:92-116. https://doi.org/10.2307/3003321

Ifo (2013a) Dimensionen und Auswirkungen eines Freihandelsabkommens zwischen der EU und den USA Studie im Auftrag des Bundesministeriums für Wirtschaft und Technologie, Endbericht (dimensions and effects of a free trade agreement between the EU and the US - study for the Ministry of Economic Affairs of the German government), Munich

Ifo (2013b) Bertelsmann Stiftung (2013), Bundesländer, Branchen und Bildungsgruppen, Wirtschaftliche Folgen eines Transatlantischen Freihandelsabkommens (THIP) für Deutschland, Mikroökonomische Analyse (written by Felbermayr, G.; Lehwald, S., Schoof, U.; Ronge, M.), Bertelsmann Stiftung, Gütersloh

IMF (2019) World Economic Outlook, October 2019: Global manufacturing downturn, Rising Trade Barriers, International Monetary Fund, Washington DC

Jungmittag A (2016) Techno-Globalisierung (techno-globalization). Contribution to the project ,EUStrukturwandel, Leitmärkte und techno-Globalisierung“, Hans-Böckler-Stiftung, Düsseldorf, forthcoming

Keller W (2000) Geographic localization of international technology diffusion. NBER Working Paper No. 7509, National Bureau of Economic Research, Cambridge, MA

Machlup F (1979) Stocks and flows of knowledge. Kyklos 32(1-2):400-411

Marrocu E, Paci R, Usai S (2013) Knowledge production function and proximities: evidence from spatial regression models for the European region. WP4/01 SEARCH Working Paper, SEARCH

McMorrow K, Orlandi F, Raciborski R, Roeger W, Vandermeulen V, in'tVeld J, Vogel L (2016) Medium term economic dynamics of the euro area. Int Econ Econ Policy 13:27-43. https://doi.org/10.1007/s10368015-0324-0m

Melitz MJ (2003) The Impact of Trade on Intra-Industry Reallocations and Aggregate Industry Productivity. Econometrica 71:1695-1725. https://doi.org/10.1111/1468-0262.00467

Perret JK (2014) Knowledge as a driver of regional growth in the Russian Federation. Springer, Heidelberg and New York

Pesaran MH, Shin Y, Smith RJ (2001) Bounds testing approaches to the analysis of level relationships. J Appl Econ 16:289-326. https://doi.org/10.1002/jae.616

Pew Research Center (2015) Is Europe on board for a new trade deal with the U.S.? Online: http://www. pewresearch.org/fact-tank/2015/01/29/is-europe-on-board-for-a-new-trade-deal-with-the-u-s/ last accessed 20.12.2019

Shan W, Zhang S (2010) The Treaty of Lisbon: Half way toward a common investment policy. Eur J Int Law 21:1049-1073. https://doi.org/10.1093/ejil/chq071

Welfens PJJ (2011) Innovations in macroeconomics. $3^{\text {rd }}$ revised and enlarged edition, springer, Heidelberg and New York

Welfens PJJ (2016) Schumpeterian macroeconomic production function for open economies: a new endogenous knowledge and output analysis. EIIW Discussion Paper No. 211, European Institute for International Economic Relations (EIIW) at the University of Wuppertal. Paper presented at the $16^{\text {th }}$ International Joseph A. Schumpeter Society conference, Montreal, July 6-8, 2016

Welfens PJJ (2017) An Accidental BREXIT. Palgrave Macmillan, London

Welfens PJJ (2019) The Global Trump - Structural US Populism and Economic Conflicts with Europe and Asia. Palgrave Macmillan, London

Welfens PJJ, Baier F (2018) BREXIT and Foreign Direct Investment: Key Issues and New Empirical Findings. Int J Financial Stud 6(2):46. https://doi.org/10.3390/ijfs6020046

Welfens PJJ, Irawan T (2014) Trade and foreign direct investment: new theoretical approach and empirical findings for US exports and European exports. EIIW Discussion Paper No. 204, European Institute for International Economic Relations (EIIW) at the University of Wuppertal, forthcoming in Int Econ Econ Policy

Welfens PJJ, Korus A, Irawan T (2014) Transatlantisches Freihandels- und Investitionsabkommen (Transatlantic Trade and Investment Partnership). Lucius, Stuttgart

Welfens PJJ, Meyer B, Pfaffenberger W, Jasinski P, Jungmittag A (2001) Energy policies in the European Union - Germany's ecological tax reform. Springer, Heidelberg and Berlin

Publisher's note Springer Nature remains neutral with regard to jurisdictional claims in published maps and institutional affiliations. 


\section{Affiliations}

\section{Andre Jungmittag ${ }^{1}$ • Paul J. J. Welfens ${ }^{2,3,4}$}

Andre Jungmittag

jungmitt@fb3.fra-uas.de

1 Economics and Quantitative Methods, Frankfurt University of Applied Sciences, Frankfurt, Germany

2 Chair of Macroeconomics and Jean Monnet Chair for European Economic Integration, European Institute for International Economic Relations (EIIW) at the University of Wuppertal, University of Wuppertal, Schumpeter School of Business and Economics, Rainer-Gruenter-Str., D-42119 Wuppertal, Germany

3 AICGS/Johns Hopkins University, Washington, DC, USA

4 IZA Institute of Labor Economics, Bonn, Germany 